Wspólnym rysem studiów zawartych w części pierwszej i drugiej jest akcentowanie osoby nauczyciela, naukowca, badacza, twórcy, artysty. Wybitnych nauczycieli, naukowców, badaczy, twórców, artystów, którzy wywarli określony wpływ na kształtowanie czlowieka, rozwój nauki, twórczości artystycznej i towaIzyszącej im najczęściej filozofii życia można znależć, mimo kontrowersyjności naszej epoki, we współczesnej historii niezliczone rzesze. Pragniemy utrwalić i przekazać następnym pokoleniom ich ofiarność i trud. Historiografowie po przezwyciężeniu uproszczeń o determinującej roli wybitnych jednostek „nie moga zrezygnować z eksponowania postaci historycznych, które ogniskowały $w$ sobie przelomowe momenty historii" (K. Kwaśniewski, Spoleczne rodowody bohaterów, Warszawa 1977, s. 6). Wspólczesny człowiek chce coraz więcej wiedzieć o swojej historii, przy czym poszukuje o niej wiedzy - nazwijmy ją - konkretnej. Ona bowiem bardziej przemawia do ludzkiej wrażliwości i całej osobowości człowieka.

Tymi zaś konkretami są dla wielu relacje o ludziach, którzy tworzyli naszą przeszłość. Deskrypcja o nich, przy stałej trosce o unikanie błędów hagiografizmu zbliża w sposób istotny może najbardziej ,...do pasjonującego procesu tworzenia historii" (A. Gąsiorowski, J. Topolski, Wstep, w: Welkopolski slownik biograficzny, Warszawa - Poznań 1981, s. 9 ).

Ma to szczególne znaczenie, gdy kwestie te rozpatrujemy w aspekcie rozwoju danej społeczności, a jeszcze ściślej, gdy rzecz odnosi się do regionu, czy miasta.

$\mathrm{W}$ ten kontekst wchodzą przedstawione w pracy studia. Traktowane komplementarnie prezentują w sposób pogłębiony rolę i znaczenie lódzkiego środowiska nauczycielskiego, naukowego $\mathrm{i}$ artystycznego $\mathrm{w}$ tworzenie dziedzictwa kulturowego Lodzi. Praca wzbogaca niewątpliwie bogatą literaturę historyczną i historyczno-oświatową dotyczącą dziejów Lodzi i specyficznych przejawów życia tego miasta, swoistego ośrodka naukowego, edukacyjnego, a przede wszystkim przemysłowego.

Wnosi ona także ważki wkład do historii polskiej pedeutologii. Należy także zauważyć i podkreślić rolę mecenatu Prezydenta Miasta Lodzi w wydaniu tej publikacji jako przykład sponsoringu godny naśladowania.

Jan Hellwig

\title{
Jadwiga Suchmiel, Dzialalność naukowa kobiet w Uniwersytecie we Lwowie do roku 1939, Częstochowa 2000, Wydawnictwo Wyższej Szkoly Pedagogicznej w Częstochowie, ss. 369
}

Jadwiga Suchmiel opublikowała prace poświęconą działalności oraz silnym wówczas tendencjom edukacyjnym kobiet w Uniwersytecie we Lwowie do 1939 roku.

Jest to opracowanie dotyczące aktywizacji naukowej, w oparciu o podstawy formalno-prawne, pierwszych czynnych na tym polu kobiet w Polsce. Obejmuje ono środowisko naukowe $\mathrm{i}$ role $\mathrm{w}$ nim kobiet, drugiego polskiego Uniwersytetu, obok Uniwersytetu Jagiellońskiego, w okresie galicyjskiej autonomii oraz w Drugiej Rzeczypospolitej, mianowicie Uniwersytetu we Lwowie.

Celem niniejszego opracowania było przedstawienie procesu wejścia kobiet ze Lwo- wa oraz całego obszaru wschodniej Galicji na droge tworzenia i kształcenia inteligencji polskiej.

Konstrukcja pracy składa się ze wstępu, charakterystyki źródel oraz z trzech zasadniczych części.

Pierwsza część obejmuje inicjatywy, głównie na terenie Lwowa i Galicji, które przyczyniły się do uzyskania możliwości edukacyjno-naukowych dla kobiet w Uniwersytecie we Lwowie. Przedstawione sq ważniejsze okoliczności, które złożyły się na proces uzyskiwania wykształcenia naukowego kobiet, tzn. zdobywania kolejnych stopni na szczeblach kariery naukowej - stopnia doktora, habilitacji oraz 
możliwości wykonywania zawodu pracownika nauki. Autorka ukazuje klimat, w którym kobiety tworzyły wszelkie inicjatywy kształcące i wspierające ich dążenia i aspiracje edukacyjne, które prowadziły także do zmian mentalności szerokiego ogółu społeczeństwa, postrzegając kobietę jako wykształconą partnerkę także na płaszczyźnie zawodowej. J. Suchmiel w części tej przedstawia rozmaite formy działalności kobiet [pensje dla dziewcząt prowadzone przez wykształcone kobiety, działalność Towarzystwa Pedagogicznego jako organizatora systematycznych kursów dla kobiet, powstała w 1884 roku "Czytelnię dla Kobiet", zawodowe stowarzyszenia nauczycielek we Lwowie, I Kongres Pedagogów Polskich we Lwowie w roku 1894 (oficjalnie wypowiadający się za otwarciem uniwersytetów dla kobiet)]. Przyczyniły się one bezpośrednio do podjęcia ważnych decyzji na szczeblu ministerialnym zapoczątkowujących daleko idace zmiany w statusie społecznym kobiet polskich.

Autorka przedstawia również „trudne" początki studiów na dwóch dostępnych dla kobiet wydziałach, tzn. Wydziale Lekarskim oraz Wydziale Filozoficznym Uniwersytetu Lwowskiego, ukazuje proces rekrutacji oraz stopniowego wzrostu liczby kobiet na Uczelni. Charakterystyczne w tej części pracy jest ukazanie atmosfery, jaka towarzyszyła wówczas regulacji studiów dla kobiet, przychylności lub jej braku wśród profesorów, co niewątpliwie podnosi walory rozprawy.

Część druga ukazuje funkcjonowanie Uniwersytetu w warunkach autonomii galicyjskiej oraz obejmuje charakterystykę wydoktoryzowanych kobiet w tym okresie. J. Suchmiel podkreśla tutaj ogromne znaczenie udziału kobiet $w$ procesie podnoszenia poziomu kwalifikacji, jaki miał miejsce w Uniwersytecie Lwowskim w okresie autonomii Galicji. Charakteryzuje pochodzenie społeczne kobiet oraz droge ich kariery naukowej w Uniwersytecie Lwowskim. Charakterystyka owa dotyczy ksztalcacych się wówczas kobiet, ich pochodzenia, ocen zdobytych z poszczególnych egzaminów doktorskich, tytułów rozpraw, praktyki zawodowej. Autorka w części tej dokonuje podziału na: doktoraty medyczne uzyskane w latach
1904 - 1917/18 oraz doktoraty na Wydziale Filozoficznym uzyskane w latach 1904/5 - 1917/18 z wyszczególnieniem: Historii, Filologii Germańskiej, Filologii Polskiej, Zoologii, Chemii, Filozofii Ścisłej, Botaniki, Historii i Teorii Muzyki, Geografii oraz Historii Sztuki. J. Suchmiel przybliża również sylwetki pierwszych asystentek Uniwersytetu Lwowskiego stanowiących wówczas nieliczną grupe pracowników uczelni.

Część trzecia dotyczy okresu Drugiej Rzeczypospolitej, w którym najwięcej kobiet uzyskało stopnie doktora oraz miały wówczas miejsce pierwsze habilitacje. Okres międzywojenny, dzięki odpowiednim przepisom, charakteryzował się intensywnym uaktywnieniem kobiet w edukacji akademickiej. Kobiety nie tylko studiowały i nie tylko zdobywały stopnie doktorskie, ale również w okresie tym sięgały po pierwsze habilitacje. Zdecydowanie wzrosła ich aktywność zawodowa. Zjawisko to przybliża autorka, ukazując przede wszystkim trudny proces wejścia kobiet w grupe zawodową, np. lekarzy czy nauczycieli, a także przedstawiając niezwykle ożywioną działalność kobiet w zakresie pracy społecznej, ekonomicznej, filantropijnej. Ważnym elementem pracy jest przedstawienie sylwetek kobiet posiadających bogaty dorobek pisarski w wielu dyscyplinach. W rozdziale tym J. Suchmiel charakteryzuje również uzyskane doktoraty i habilitacje, dokonując podziału ma doktoraty medyczne uzyskane w latach 1918/19-1939 oraz doktoraty filozofii i habilitacje kobiet uzyskane w latach 1918/19 - 1939.

Jak podkreśla J. Suchmiel, od pierwszych lat odrodzonej Polski w Uniwersytecie Jana Kazimierza panował przychylny klimat dla studiów i karier naukowych kobiet, co niewątpliwie sprzyjało znacznemu wzrostowi liczby wykształconych kobiet.

Zamknięciem pracy, a także podstawa opracowania jest imienny wykaz wszystkich kobiet ze stopniem doktora, które uzyskały dyplom $z$ poszczególnych dyscyplin, tj. medycyny, prawa oraz filozofii $w$ Uniwersytecie we Lwowie w latach $1903-1939$, sporządzony na bazie źródłowej: Albumów Promocyjnych za lata 1900-1916/17 oraz 1918/19 - 1937, Protokołu Komisji Wydziału Humanistycznego 
1932-1939, Protokolu Egzaminów Ścisłych Wydziału Lekarskiego, a także Księgi rygorozalnej Wydziału Filozoficznego. Jest to sumiennie sporządzony alfabetyczny spis obejmujący nazwisko $i$ imię lub imiona, miejsce urodzenia, datę urodzenia (ustaloną $\mathrm{z}$ innych źródeł niż wyżej podane), dyscyplinę, rok promocji, temat pracy doktorskiej, imię i nazwisko promotora.

Rozprawa Jadwigi Suchmiel oparta została na bogatym materiale źródłowym. Istotna część tej podstawy źródlowej stanowią materiały archiwalne pochodzące $\mathrm{z}$ Państwowego Archiwum Obwodowego we Lwowie.

Cennym drukowanym materiałem źródłowym wykorzystanym w pracy są również kolejne roczniki Skladu Uniwersytetu, które ukazy- wały się nieprzerwanie od roku 1876 do 1939 oraz Kronika Uniwersytetu Jana Kazimierza we Lwowie obejmująca lata 1920-1930.

W pracy zostały uwzględnione także bibliografie ukazujące się do 1939 roku, Polski Slownik Bibliograficzny, słowniki biograficzne obejmujące badaczy poszczególnych dyscyplin, wydawnictwa encyklopedyczne, materiały pamiętnikarskie i autobiograficzne.

Oceniając książke J. Suchmiel należy stwierdzić, że wśród rezultatów dotychczasowych badań nad edukacją i dzialalnością naukowa kobiet do 1939 roku, pozycja ta znacznie rozszerza i wzbogaca wydaną dotychczas literature na ten temat.

Justyna Gulczyniska

\section{Stefan Woloszyn, Nauki o wychowaniu w Polsce w XX wieku. Próba syntetycznego zarysu na tle powszechnym, wyd. II po- szerzone, Dom Wydawniczy Strzelec, Kielce 1998, ss. 282}

Nieco spóźniona nota o bardzo oczekiwanej książce, która przemknęła jak mglawica przez księgarnie - nie wymaga więc reklamy ale raczej odnotowania, że się pojawiła i konstatacji o dalszym zapotrzebowaniu rynku oraz zasygnalizowania różnic pomiędzy pierwszym i drugim wydaniem.

Książką którą zapowiada powyższy wstęp jest wydanie drugie poszerzone Stefana Woloszyna „Nauki o wychowaniu w Polsce w XX wieku, próba syntetycznego zarysu na tle powszechnym". Książkę wydał Dom Wydawniczy STRZELEC w Kielcach w 1998 r. nakładem autora. $\mathrm{Na}$ odwrocie strony tytułowej, zgodnie ze sztuką edytorską mamy informację o pierwszym wydaniu przez Instytut Badań Edukacyjnych w Warszawie, w 1992 r.

Obydwa wydania różnia się formatem, objętością i zakresem treści a także, i to najbardziej, układem graficznym i szatą graficzną Broszurowe pierwsze wydanie w formacie zeszytowym, napisane bylo drobnym niemal ciagłym $i$ jednolitym drukiem, nie ułatwiało szybkiego znajdywania nazwisk i utrudniało czytanie. Nowe, drugie wydanie jest przykładnym, nowoczesnym rozwiązaniem graficznym, jakie nauczyliśmy się już doceniać czytając polskie thumaczenia obcojęzycznych podręczników.

Główne części podręcznika są niezmienne w obydwu wydaniach a tytuły rozdziałów w większości brzmią identycznie. W wydaniu drugim największym zmianom uległ rozdział kolejny czwarty: „Nowe nurty ostatnich dziesięcioleci" zamiast tytułu z pierwszego wydania: „Nowe nurty wspólczesne”. Do dotychczasowych podrozdziałów dołączono w drugim wydaniu dodatkowe, omawiające najaktualniejszą i najmodniejszą problematykę rozważaną przez współczesną pedagogikę. Oto ich tytuły: „Nowe nurty ostatnich dziesięcioleci”, „Ruchy kontestacyjne i kontrkultura", "New Age - czy nowa wizja życia?" oraz „Problemy pedagogiczne ery komputeryzacji i elektroniki - czy koniec Ery Gutenberga?"'. Autor poczynił też zmiany wewnątrz opracowania podrozdziałów, których tytuły pozostały niezmienione. Dla przykładu podrozdziały: „Nurt radykalnej krytyki szkoły”, „Poszukiwanie nowych strategii edukacyjnych" zostały bardzo rozbudowane i oczywiście uzupetnione o dorobek naukowy tych dziedzin 